-Full Paper-

\title{
Production of Transgenic and Non-Transgenic Clones in Miniature Pigs by Somatic Cell Nuclear Transfer
}

\author{
Mayuko KUROME1), Takayuki ISHIKAWA ${ }^{2)}$, Ryo TOMII'), Satoshi UENO'1), Arata SHIMADA ${ }^{1)}$, \\ Hajime YAZAWA ${ }^{2)}$ and Hiroshi NAGASHIMA ${ }^{1)}$ \\ ${ }^{1)}$ Laboratory of Developmental Engineering, Department of Life Science, Meiji University, Kawasaki 214-8571 and \\ 2) Laboratory Animal Research Station, Nippon Institute for Biological Science, Hokuto 408-0041, Japan
}

\begin{abstract}
Miniature pigs have been recognized as valuable experimental animals in various fields such as medical and pharmaceutical research. However, the amount of information on somatic cell cloning in miniature pigs, as well as genetically modified miniature pigs, is much less than that available for common domestic pigs. The objective of the present study was to establish an efficient technique of cloning miniature pigs by somatic cell nuclear transfer. A high pregnancy rate was achieved following transfer of parthenogenetic (3/3) and cloned (5/6) embryos using female miniature pigs in the early pregnancy period as recipients after estrus synchronization with prostaglandin F2 alpha analog and gonadotrophins. The production efficiency of the cloned miniature pigs using male and female fetal fibroblasts as nucleus donors was $0.9 \%(2 / 215$ and $3 / 331$, respectively). Cloned miniature pigs were also produced efficiently $(7.8 \%, 5 / 64)$ by transferring reconstructed embryos into the uteri of common domestic pigs. When donor cells transfected with the green fluorescent protein (GFP) gene were used in nuclear transfer, the production efficiency of the reconstructed embryos and rate of blastocyst development were comparable to those obtained by non-transfected cells. When transfected cell-derived reconstructed embryos were transferred to three common domestic pig recipients, all became pregnant, and a total of ten transgenic cloned miniature pigs were obtained (piglet production efficiency: $2.7 \%, 10 / 365)$. Hence, we were able to establish a practical system for producing cloned and transgenic-cloned miniature pigs with a syngeneic background.
\end{abstract}

Key words: Embryo transfer, In vitro matured oocyte, Miniature pig, Nuclear transfer, Transgenic

(J. Reprod. Dev. 54: 156-163, 2008)

$\mathrm{n}$ recent years, techniques for producing cloned pigs by somatic cell nuclear transfer (SCNT) have been actively utilized to produce genetically modified pigs. A number of cloned pigs have been produced, including those with genes for GFP [18], as well as alpha1,3-galactosyltransferase knockout pigs [9-16]. In this manner, genetically modified pigs are being used in a wide variety of biomedical fields, ranging from basic research to organ transplantation.

To date, more than ten breeds of miniature pigs have been established as experimental and companion animals [17]. As far as the use of pigs as experimental animals is concerned, miniature pigs are smaller and easier to handle than common domestic pigs, and they have been used in a variety of fields, such as medical and pharmacological research [10, 18-25]. However, compared with common domestic pigs, far less information regarding the production of cloned and genetically modified pigs is available for miniature pigs [10, 13, 14, 26-31].

In the present study, we conducted a series of experiments including (i) validation of an estrus synchronization procedure for miniature pig recipients, (ii) examination of the developmental competence of nuclear transfer embryos reconstructed with various nuclear donor cells and (iii) comparison of miniature pigs and common domestic pigs as recipients. The results indicate that it is possible to produce cloned miniature pigs using common domestic

Accepted for publication: January 21, 2008

Published online: February 25, 2008

Correspondence: H. Nagashima (e-mail: hnagas@isc.meiji.ac.jp) pigs as the recipients and to produce genetically modified-cloned miniature pigs with a level of efficiency comparable to that for conventionally cloned miniature pigs.

\section{Materials and Methods}

\section{Animal care}

All animal experiments in this study were approved by the Institutional Animal Care and Use Committee of Meiji University (IACUC-03-005).

\section{Chemicals}

All chemicals were purchased from Sigma-Aldrich Chemical (St. Louis, MO, USA), unless otherwise indicated.

\section{Preparation of donor cells}

Primary culture fetal fibroblasts were used as nucleus donor cells in SCNT. Fetal fibroblasts were obtained from 30-day-old fetuses that were produced by mating NIBS strain miniature pigs (Laboratory Animal Research Station, Nippon Institute for Biological Sciences, Hokuto, Japan). The head, viscera and bones of each fetus were removed and washed three times using Dulbecco's phosphate buffered saline (D-PBS). The washed tissue was finely chopped into fragments smaller than $1 \mathrm{~mm}$ in size, and the tissue fragments were placed in 35-mm culture dishes (Falcon Primaria; Becton Dickinson, Franklin Lakes, NJ, USA) and incubated for 30 min in a humidified incubator at $38.5 \mathrm{C}$ with $5 \% \mathrm{CO}_{2}$. After con- 
firming that the tissue fragments adhered to the culture dish, a highglucose Dulbecco's modified Eagle medium (GIBCO Invitrogen, Grand Island, NY, USA) containing 15\% fetal calf serum (FCS; JRH Biosciences, Lenexa, KS, USA) was gently added. At 2-3 days later, the tissue fragments were removed, and the cells adhering to the bottom of the culture dish were cultured. After three to four passages, the cells were stored frozen according to the conventional methods.

\section{Transfer of the GFP gene into miniature pig fetal fibroblasts}

The GFP-neo fusion gene under control of the pgk promoter (pQBI-pgk, AFP2043; Qbiogene, CA, USA) was used for gene transfer. Using FuGENE-6 transfection reagent (1814443; Roche, Indianapolis, IN, USA), gene transfer was carried out according to the manufacturer's instructions. Briefly, a mixture of the transfection reagent and pQBI-pgk GFP vector, which was linearized using a restriction enzyme (PvuI; 3:1 mixture), was added to cells $(1.0 \times$ $10^{5}$ cells/35-mm culture dish) and incubated for $24 \mathrm{~h}$. According to the conventional methods, the cells recovered from the dish were seeded in 48-well plates ( $2-3 \times 10^{3}$ cells/well). At $48 \mathrm{~h}$ after gene transfer, the cells were incubated in standard culture medium including $250 \mu \mathrm{g} / \mathrm{ml}$ of G418 (Geneticin, 11811-023; GIBCO). Colonies resistant to G418 were subcultured in 4-well plates. Cells exhibiting GFP fluorescence under fluorescence microscopy were selected, and after two or three passages, the resulting cells were stored frozen in liquid nitrogen $\left(6.0 \times 10^{5}\right.$ cells $\left./ \mathrm{ml}\right)$ until SCNT.

\section{In vitro maturation of oocytes}

Ovaries were collected at a local abattoir and transported to the laboratory in D-PBS containing $75 \mu \mathrm{g} / \mathrm{ml}$ potassium penicillin $\mathrm{G}$, $50 \mu \mathrm{g} / \mathrm{ml}$ streptomycin sulfate and $0.1 \%(\mathrm{w} / \mathrm{v})$ polyvinyl alcohol (PVA). Cumulus-oocyte complexes (COCs) were collected from the antral follicles (3.0-6.0 mm in diameter) by aspiration. COCs displaying at least three layers of compacted cumulus cells were selected and cultured in NCSU23 medium [32] supplemented with $0.6 \mathrm{mM}$ cysteine, $10 \mathrm{ng} / \mathrm{ml}$ epidermal growth factor, $10 \%$ (v/v) porcine follicular fluid, $75 \mu \mathrm{g} / \mathrm{ml}$ potassium penicillin G, $50 \mu \mathrm{g} / \mathrm{ml}$ streptomycin sulfate, $10 \mathrm{IU} / \mathrm{ml}$ equine chorionic gonadotropin (eCG; Teikoku Hormone Medical, Tokyo, Japan) and $10 \mathrm{IU} / \mathrm{ml}$ human chorionic gonadotropin (hCG; Teikoku Hormone Medical). The COCs were cultured for $22 \mathrm{~h}$ with eCG and hCG and then for $20 \mathrm{~h}$ without these hormones in a humidified atmosphere of 5\% $\mathrm{CO}_{2}$ and $95 \%$ air at $38.5 \mathrm{C}$.

In vitro matured (IVM) oocytes with expanded cumulus cells were treated with $1 \mathrm{mg} / \mathrm{ml}$ hyaluronidase dissolved in Tyrode's lactose medium supplemented with $10 \mathrm{mM}$ Hepes and $0.3 \%(\mathrm{w} / \mathrm{v})$ polyvinylpyrrolidone (Hepes-TL-PVP) and were denuded of cumulus cells by gentle pipetting. Oocytes showing evenly granulated ooplasm and extrusion of the first polar body were selected for the subsequent experiments.

\section{Induction of parthenogenetic development of oocytes}

IVM oocytes were washed twice in an activation solution consisting of $0.3 \mathrm{M}$ mannitol, $50 \mu \mathrm{M} \mathrm{CaCl}_{2}, 100 \mu \mathrm{M} \mathrm{MgSO}_{4}$ and $0.01 \%$ PVA (300 mOsm), placed between the two wire electrodes (1 mm apart) of a fusion chamber slide and overlaid with $0.1 \mathrm{ml}$ of the activation solution. A single direct current (DC) pulse of 150 $\mathrm{V} / \mathrm{mm}$ was applied for $100 \mu$ sec using a somatic hybridizer (SSH-1; Shimadzu, Kyoto, Japan). The activated oocytes were treated with $5 \mu \mathrm{g} / \mathrm{ml}$ cytochalasin B (CB) for $3 \mathrm{~h}$ to suppress extrusion of the pseudo-second polar body.

\section{Somatic cell nuclear transfer}

SCNT was performed using IVM oocytes as recipient cytoplasts, as described previously [7, 33]. Enucleation was performed using a chemically assisted method developed by Yin et al. [34]. Oocytes were cultured in NCSU23 medium supplemented with 0.1 $\mu \mathrm{g} / \mathrm{ml}$ demecolcine, $0.05 \mathrm{M}$ sucrose (Nacalai Tesque, Tokyo, Japan) and $4 \mathrm{mg} / \mathrm{ml}$ bovine serum albumin for $0.5-1 \mathrm{~h}$ and then enucleated by aspirating the first polar body and adjacent cytoplasm using a bevelled pipette (30 $\mu \mathrm{m}$ in diameter) in Hepes-TLPVP containing $0.1 \mu \mathrm{g} / \mathrm{ml}$ demecolcine, $5 \mu \mathrm{g} / \mathrm{ml} \mathrm{CB}$ and $10 \%$ FCS. When a protrusion was observed on the surface of an oocyte, it was removed along with the polar body. Enucleation was confirmed by staining the cytoplasts with $5 \mu \mathrm{g} / \mathrm{ml}$ bisbenzimide (Hoechst 33342).

The nuclear donor cells were used after cell cycle synchronization by serum starvation for $48 \mathrm{~h}$. A single donor cell was inserted into the perivitelline space of each enucleated oocyte. Donor celloocyte complexes were placed in a $280 \mathrm{mM}$ mannitol (Nacalai tesque) solution ( $\mathrm{pH} 7.2$ ) containing $0.15 \mathrm{mM} \mathrm{MgSO}_{4}, 0.01 \%(\mathrm{w} / \mathrm{v})$ PVA and $0.5 \mathrm{mM}$ Hepes and held between two electrode needles. Membrane fusion was induced with a somatic hybridizer (SSH-1; Shimadzu) by applying a DC pulse (200 V/mm, $20 \mu$ secx 1$)$ and a pre- and post-pulse alternating current (AC) field of $5 \mathrm{~V}, 1 \mathrm{MHz}$ for $5 \mathrm{sec}$, respectively. The reconstructed embryos were cultured in NCSU23 for $1-1.5 \mathrm{~h}$ and then subjected to electrical activation. Activation of the reconstructed embryos was performed as described above.

\section{Culture of reconstructed embryos}

The developmental capacities of nuclear transfer embryos reconstructed with the non-transfected and transfected fetal fibroblast cells were first examined by in vitro culture. At least three independent experiments were replicated. In vitro culture of the embryos was performed in $20 \mu \mathrm{l}$ droplets of Porcine zygote medium (PZM) [35] under paraffin oil in a plastic Petri dish maintained under a humidified atmosphere of $5 \% \mathrm{CO}_{2}, 5 \% \mathrm{O}_{2}$ and $90 \%$ $\mathrm{N}_{2}$ at 38.5 C. For culturing embryos beyond the morula stage, $10 \%$ $(\mathrm{v} / \mathrm{v})$ FCS was added to the medium.

Cleavage and blastocyst formation of the reconstructed embryos were monitored during culture for 7 days. Blastocysts derived from the transfected cells were examined under fluorescent microscopy (TE300; Nikon, Tokyo, Japan) for GFP expression. On Day 7 the blastocyst cell number was also counted after fixation and staining.

\section{Estrus synchronization of recipient pigs and embryo transfer}

Sexually mature NIBS miniature pigs (aged 8-12 months with body weights of 28-32 kg) and prepubertal crossbred common domestic pigs (Large white/Landrace $\times$ Duroc aged 6.5-7 months with body weights of 100-105 kg) were used as embryo transfer recipients. 
Pregnant miniature pigs were aborted by an i.m. injection of 0.3 mg of a prostaglandin F2 alpha analog (Cloprostenol; Estrumate, Schering-Plough Animal Health, Tokyo, Japan) between 25 and 40 days after mating followed by a second injection of $0.15 \mathrm{mg}$ of Cloprostenol $24 \mathrm{~h}$ later. Two hundred and fifty international units (IU) of eCG were administered (i.m.) at the same time as the second Cloprostenol injection. In recipients with confirmed abortion, 120 IU of hCG was administered (i.m.) approximately $72 \mathrm{~h}$ after the eCG , and estrus was checked on the same or next day.

Prepubertal common domestic pigs were treated with a single i.m. injection of 1,000 IU eCG to induce estrus. Ovulation was induced by an i.m. injection of 1,500 IU hCG given $71 \mathrm{~h}$ after the injection of eCG.

Embryos were surgically transferred into the oviducts or uterine horns of the recipients after making a mid-ventral incision under general anesthesia.

\section{Experiment 1: Confirmation of the estrus synchronization procedures for the miniature pig recipients}

In order to identify a suitable time period for transferring the nuclear transfer embryos to the recipient miniature pigs, a preliminary experiment was conducted using parthenogenetic embryos prepared using IVM oocytes. Studies of cloned embryo transfer in the common domestic pigs have clarified that conception is successful when the age of the embryos is 1-2 days ahead of the number of days following ovulation [7, 15, 36, 37]. A preliminary experiment was conducted to ascertain whether this also applies to miniature pigs.

Parthenogenetic embryos approximately 24 (day 1) or 48 h (day 2) after activation were transferred to the oviducts of recipients 48 or $72 \mathrm{~h}$ after hCG administration. Based on ovulation in pigs occurring 40-42 h after hCG administration, the estrus cycle stage of the recipients was equivalent to the day of ovulation (immediately after ovulation) or the day after ovulation. At 22 days after transfer, a laparotomy was performed on the recipients to check for fetuses.

Experiment 2: In vitro assessment of the developmental capacity of cloned miniature pig embryos reconstructed with non-transfected or transfected fetal fibroblasts

The production efficiency of nuclear transfer embryos reconstructed using miniature pig fetal fibroblasts as nuclear donors and the developmental capacity of nuclear transfer embryos were investigated. Male and female fibroblasts (\#3 and \#5, respectively) confirmed to have normal chromosome compositions ( $\geq 70 \%)$ were used as the nuclear donor cells.

Of these cells, female cells (\#5) were transfected with the GFP gene, and the developmental capacities of the embryos reconstructed using the transfected cells were compared with those of embryos reconstructed using non-transfected cells.

\section{Expriment 3: In vivo assessment of the developmental capacity} of cloned miniature pig embryos

In this experiment, the developmental capacity of miniature pig embryos after transfer was investigated. The same three cells used in the in vitro experiment (Exp. 2) were used as nuclear donors.
Miniature pigs and common domestic pigs were used as recipients to ascertain the effects of different recipients on the production efficiency of cloned piglets.

Embryos reconstructed using non-transfected cells were cultured for 1 or 2 days, and morphologically normal embryos (1-cell stage on Day 1 and 2- to 8-cell stage on Day 2) were selected and transferred to the ampullae of the oviducts of the recipient miniature pigs. In addition, some reconstructed embryos were cultured in vitro for 3 days, and morphologically normal embryos in the 4cell to early morula stages were transferred to the uterine horns of common domestic pigs approximately $96 \mathrm{~h}$ after hCG administration.

After 1 to 2 days of culture, morphologically normal embryos reconstructed using the transfected cells as the donor cells were selected and transferred to the ampullae of the oviducts of common domestic pigs about $48 \mathrm{~h}$ after hCG administration. At 113 days after embryo transfer, a caesarean section was performed to recover full term fetuses. The fetuses were sacrificed to ascertain systemic tissue GFP expression, and transgenic fetuses were identified.

\section{Statistical analysis}

For proportional data, differences between groups were analyzed using the $\chi^{2}$ test. For blastocyst cell number data, differences between groups were determined using the Student's $t$-test. The level of significance was set at $\mathrm{P}<0.05$.

\section{Results}

\section{Experiment 1: Confirmation of the estrus synchronization} procedures for miniature pig recipients

Table 1 summarizes the transfer of parthenogenetic embryos to recipients in relation to estrus synchronization. When Day 1 or Day 2 embryos were transferred to recipients on the day of ovulation or one day after ovulation, conception was achieved with comparable efficiency. Based on this finding, either Day 1 embryos or Day 1 and Day 2 embryos together were transferred to recipient miniature pigs on the expected day of ovulation in the following cloned embryo transfer experiments.

\section{Experiment 2: In vitro development of cloned miniature pig} embryos reconstructed with non-transfected or transfected fetal fibroblasts

The production efficiency of nuclear transfer embryos reconstructed using miniature pig fetal fibroblasts as nuclear donors and the in vitro development of nuclear transfer embryos is summarized in Table 2.

Regardless of the donor cell type, i.e., non-transfected cells (male \#3, female \#5) and transfected cells (origin \#5), the fusion rate of recipient oocytes and donor cells was high, ranging from $83.5 \%$ (66/79) to $90.7 \%$ (98/108). The rates of blastocyst formation were nearly equal in the three donor cell types and ranged from $13.6 \%(9 / 66)$ to $19.1 \%$ (9/47). However, the average number of blastocyst cells for the embryos reconstructed using transfected cells was significantly lower than that for the embryos reconstructed using non-transfected cells $(\mathrm{P}<0.05)$. 
Table 1. Development of IVM-derived parthenogenetic pig embryos after transfer into estrus synchronized miniature pig recipients

\begin{tabular}{ccccc}
\hline $\begin{array}{c}\text { Age of embryos } \\
(\text { day })^{1}\end{array}$ & $\begin{array}{c}\text { Days after ovulation } \\
\text { in recipients }^{2}\end{array}$ & Synchrony ${ }^{3}$ & $\begin{array}{c}\text { No. of embryos } \\
\text { transferred }\end{array}$ & $\begin{array}{c}\text { No. of fetuses } \\
\text { recovered (\%) }\end{array}$ \\
\hline 1 & 0 & +1 & 40 & $10(25.0)$ \\
2 & 0 & +2 & 40 & $6(15.0)$ \\
2 & 1 & +1 & 56 & $15(27.0)$ \\
\hline
\end{tabular}

${ }^{1}$ Days after activation. ${ }^{2}$ Ovulation was assumed to occur approximately $40-42 \mathrm{~h}$ after hCG injection. ${ }^{3}$ (Days after embryos activation)-(Days after ovulation in recipient).

Table 2. In vitro development of cloned embryos reconstructed with transfected or non-transfected donor cells in miniature pigs

\begin{tabular}{|c|c|c|c|c|}
\hline Donor cells & Fusion rates & $\begin{array}{c}\text { Normal cleavage } \\
(\%)\end{array}$ & $\begin{array}{c}\text { Blastocyst } \\
\text { formation (\%) }\end{array}$ & $\begin{array}{l}\text { Cell number in } \\
\text { blastocysts (\%) }\end{array}$ \\
\hline (male) & $\begin{array}{l}98 / 108 \\
(90.7 \%)\end{array}$ & $\begin{array}{l}68 / 98 \\
(69.4)^{\mathrm{a}}\end{array}$ & $\begin{array}{l}14 / 98 \\
(14.3)\end{array}$ & $83.1 \pm 15.2^{\mathrm{a}}$ \\
\hline (female) & $\begin{array}{c}66 / 79 \\
(83.5 \%)\end{array}$ & $\begin{array}{l}56 / 66 \\
(84.8)^{\mathrm{b}}\end{array}$ & $\begin{array}{c}9 / 66 \\
(13.6)\end{array}$ & $73.4 \pm 8.7^{\mathrm{a}}$ \\
\hline $\begin{array}{ll}\text { \#5 transfected } \\
\text { with GFP gene }\end{array}$ & $\begin{array}{c}48 / 55 \\
(87.3 \%)\end{array}$ & $\begin{array}{l}22 / 47 \\
(46.8)^{\mathrm{c}}\end{array}$ & $\begin{array}{c}9 / 47 \\
(19.1)\end{array}$ & $41.3 \pm 5.1^{b}$ \\
\hline
\end{tabular}

${ }_{\text {abc }}<0.05$.

Table 3. Production of cloned miniature pigs by nuclear transfer of fetal fibroblast cells

\begin{tabular}{|c|c|c|c|c|c|c|c|}
\hline Donor cells & Recipients & $\begin{array}{l}\text { No. of } \\
\text { recipients }\end{array}$ & $\begin{array}{c}\text { No. of } \\
\text { embryos } \\
\text { transferred }\end{array}$ & Pregnancy & Delivery & $\begin{array}{l}\text { Offspring } \\
\text { (stillborn) }\end{array}$ & $\begin{array}{l}\text { No. offspring } \\
\text { / No. embryos } \\
\text { transferred }^{1}(\%)\end{array}$ \\
\hline $\begin{array}{l}\text { \#3 } \\
\text { (male) }\end{array}$ & Mini-pig² & 3 & 314 & 2 & 1 & 2 & $\begin{array}{l}2 / 215 \\
(0.9)\end{array}$ \\
\hline$\# 5$ & Mini-pig ${ }^{2}$ & 3 & 331 & 3 & 2 & $\begin{array}{c}3 \\
(2)\end{array}$ & $\begin{array}{c}3 / 331 \\
(0.9)\end{array}$ \\
\hline (female) & $\begin{array}{l}\text { Common } \\
\text { pig }^{3 *}\end{array}$ & 2 & 131 & 1 & 1 & $\begin{array}{c}5 \\
(2)\end{array}$ & $\begin{array}{l}5 / 64 \\
(7.8)\end{array}$ \\
\hline \multicolumn{8}{|l|}{ \#5 } \\
\hline $\begin{array}{l}\text { transfected } \\
\text { with GFP gene }\end{array}$ & $\begin{array}{l}\text { Common } \\
\text { pig }^{2 *}\end{array}$ & 3 & 365 & 3 & 3 & $\begin{array}{l}10 \\
(1)\end{array}$ & $\begin{array}{c}10 / 365 \\
(2.7)\end{array}$ \\
\hline
\end{tabular}

${ }^{1}$ No. of embryos transferred in the pregnant recipients. ${ }^{2}$ Oviductal transfer. ${ }^{3}$ Uterine transfer. ${ }^{*}$ Common domestic pigs.

Expriment 3: Development of cloned miniature pig embryos after transfer

The results of transferring the cloned embryos into recipient pigs are shown in Table 3. Because influence from the recipient, such as luteal hypoplasia in pregnancy failure, can not be excluded, the calculations of cloning efficiency in Table 3 only considered the number of transferred embryos that led to a pregnancy.

Embryos that were reconstructed using male and female miniature pig fibroblasts were each transferred into three recipient miniature pigs. Following transfer of cloned embryos derived from male fibroblasts (\#3), two recipients became pregnant, and while one miscarried (Day 86), the other delivered two live piglets (Fig. 1A). Following transfer of the cloned embryos reconstructed using female fibroblasts (\#5), all recipients became pregnant, although one miscarried (Day 78). The other two recipients delivered one live piglet and two stillborn piglets. Among the 5 recipients that became pregnant, the ratio of cloned piglets produced (including stillborn piglets) to the total number of transferred embryos for the two types of donors (\#3, male, and \#5, female) was $0.9 \%$ (2/215 and 3/331, respectively).

A microsatellite analysis was conducted by sending samples obtained from the cloned miniature pigs, donor cells and recipients to a company that specializes in porcine parentage verification (Prescribe Genomics, Ibaraki, Japan), and the results confirmed that the piglets were clones of the donor cells (data not shown).

A total of 131 embryos reconstructed using female donor cells (\#5) were cultured for three days and then transferred to the uteri of two common domestic pigs. One recipient became pregnant and 

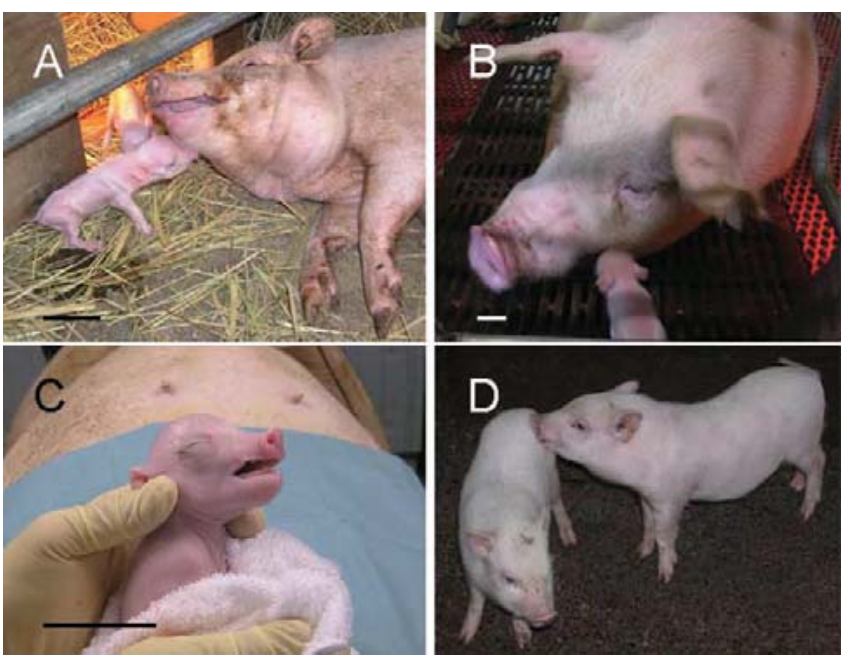

Fig. 1. Production of cloned miniature pigs by nuclear transfer of fetal fibroblast cells. Newborn cloned miniature pigs delivered from a recipient of the same strain (A) or common domestic pig (B). C: Newborn transgenic cloned piglet obtained by caesarian section of a common domestic pig recipient. D: A pair of cloned miniature pigs grown from the piglets shown in $\mathrm{A}$ at 4 months of age. The scale bars in $\mathrm{A}, \mathrm{B}$ and $\mathrm{C}$ represent $5 \mathrm{~cm}$.

delivered three live and two stillborn piglets (Fig. 1B). For the recipient that delivered, the efficiency rate of piglet production in relation to the total number of transferred embryos was $7.8 \%$ (5/ 64).

Female fibroblasts (\#5) were transfected with the GFP gene and then used as donor cells in SCNT. Following transfer of reconstructed embryos to the oviducts of three common domestic pigs, all the pigs became pregnant, and 10 live transgenic miniature piglets were obtained (including one stillborn piglet; Fig. 1C). The efficiency rate of piglet production in relation to the total number of transferred embryos was $2.7 \%$ (10/365).

The birth weights of live offspring, including full term fetuses obtained by caesarean section, were also compared. The average birth weights of the non-transgenic cloned piglets produced by transferring \#3- and \#5-derived embryos into recipient miniature pigs were 400.0 and 450.0 g (only one piglet for the \#5-derived clones), respectively. The average body weight (465.0 g) of the non-transgenic cloned piglets produced by transferring \#5-derived nuclear transfer embryos into the uterine horns of recipient common domestic pigs was comparable to that of piglets produced from recipient miniature pigs. Furthermore, the average birth weight (422.7 g) of the transgenic-cloned piglets originating from the \#5 cells transfected with the GFP gene and produced by recipient common domestic pigs was comparable to that of the nontransgenic piglets.

Unfixed small tissue pieces were collected from the brains, hearts, livers, lungs, kidneys, intestines, peritonea and skeletal muscle of cloned piglets derived from GFP-transfected cells. Clear green fluorescence was observed in all tissues except for the brain. Of these tissues, primary cultured cells were established from the heart, lung, kidney, small intestine and skeletal muscle. Observa-

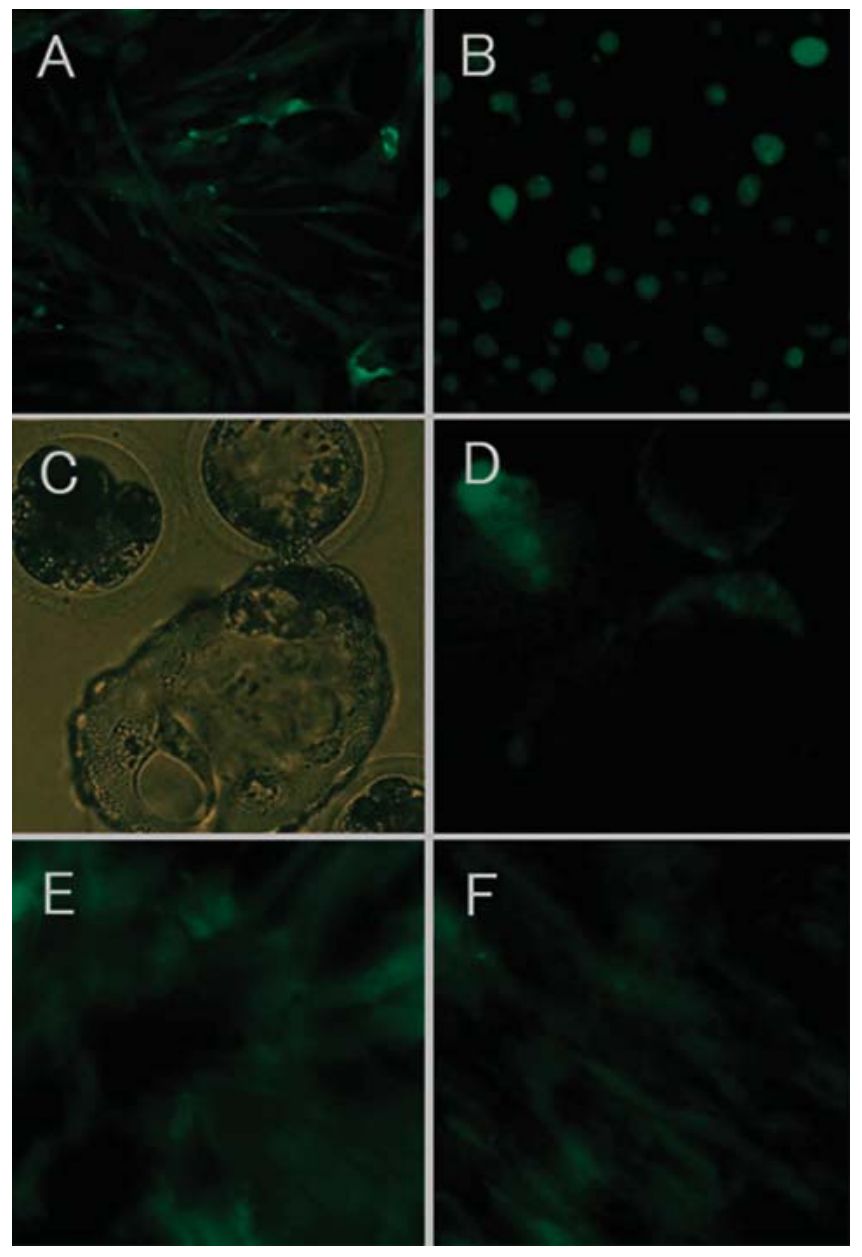

Fig. 2. Production of transgenic cloned miniature pigs from fetal fibroblast cells transfected with the GFP gene. A: Fetal fibroblast cells transfected with the GFP gene. B: Nuclear donor cells expressing GFP. C, D: A cloned blastocyst reconstructed with a transfected donor cell as observed under bright field (C) and fluorescence microscopy (B-excitation; D). E, F: Primary culture cells established from the heart (E) and lung $(\mathrm{F})$ of a transgenic cloned miniature pig expressing GFP (A-F, ×200 magnification).

tion of these cells under fluorescent microscopy confirmed clear green fluorescence in all samples. Figure 2 shows GFP-transfected nuclear donor cells, cloned blastocysts obtained by nuclear transfer and primary cultured cells originating from a cloned piglet.

\section{Discussion}

In recent years, a number of groups have reported successful SCNT using common domestic pigs [4, 7, 8, 15, 34, 36-46]. If SCNT became widely available for miniature pigs, the usefulness of miniature pigs as experimental animals would markedly improve. Since there is as yet no evident inbred strain of miniature pigs, cloned miniature pigs should allow highly accurate and precise studies using animals of the same genetic background.

The production of cloned piglets by SCNT requires several 
steps, including preparation of donor cells and recipient oocytes along with artificial activation and culture of reconstructed embryos, and ultimately the cloned embryos are transferred to surrogates. While several groups have documented estrus cycle synchronization and embryo transfer in miniature pigs, there is no established method [23, 26, 47-52]. In our conventional embryo transfer efforts in common domestic pigs, eCG is administered to pigs just prior to puberty, and hCG is administered $72 \mathrm{~h}$ later. Stable results have been achieved using this technique [7, 15, 36, 37]. Similarly, several studies have reported estrus synchronization in miniature pigs by administering eCG and hCG just prior to puberty [47-49, 51], but the optimal time for gonadotropin administration in NIBS miniature pigs prior to puberty has not been established. Furthermore, NIBS miniature pigs reach puberty early at 3 to 4 months after birth, and it has not been clarified whether or not gilts at these ages are suitable as recipients of embryo transfer. Hence, in the present study, we synchronized estrus by artificially inducing abortion in pregnant miniature pigs. Estrus synchronization combined with induced abortion by administration of a prostaglandin F2 alpha analog and gonadotropin has been performed for years in common domestic pigs [53]. The present study suggests that this technique is also effective in miniature pigs and that estrus can be synchronized in a reliable manner.

In addition, as is the case with embryo transfer into common domestic pigs, the results of the present study confirmed that conception occurs when the embryonic age is 1 to 2 days ahead of the number of days after ovulation. Thus, the basic technique for using miniature pigs as recipients for cloned pig production has been established.

The fact that the present study showed that cloned miniature piglets could be successfully produced using common domestic pigs as recipients is significant for the utility of cloning miniature pigs. Compared with miniature pigs, common domestic pigs can accommodate more fetuses, and as a result, they are suitable for producing many piglets per pregnancy. The production efficiency of cloned piglets using common domestic pigs as recipients tended to be higher compared to that obtained using recipient miniature pigs, although there was no clear statistical difference due to the small number of transfer experiments.

When using common domestic pigs as recipients, management of labor and delivery is very important. Crossbred common domestic pigs weigh about three times as much as NIBS miniature pigs, and the average birth weight of miniature pigs is less than half that of common domestic pigs. If neonatal miniature pigs produced by surrogate common domestic pigs can be safely nursed using artificial milk, then producing cloned miniature pigs in this way is very practical. In fact, when producing transgenic miniature pigs expressing GFP from recipient common domestic pigs, the survival of full-term piglets obtained by a caesarean section was very high (9/10). These results indicate the advantage of using recipient common domestic pigs for producing value-added clones, such as, transgenic cloned miniature pigs.

Transfer of nuclear transfer embryos to the uterus is also effective for producing cloned miniature pigs. In uterine transfer, nuclear transfer embryos are cultured for three days; however, due to recent advances in porcine embryo culture media [35], this degree of in vitro culture apparently does not compromise embryo survival. In recent years, Ueno et al. [54] have suggested the possibility of embryonic loss in transferring cloned embryos with damaged zona pellucida to the oviduct. In order to avoid such a latent risk, transferring cloned embryos to the uterus appears to be more practical.

In the present study, common domestic pig oocytes collected from an abattoir were used as the recipient cytoplasm for miniature pig nuclear transfer; however, the effect of utilizing common domestic pig oocytes on the physiological characteristics of cloned miniature pigs has not been clarified. The average birth weight of the cloned piglets produced by recipient miniature pigs was 425.5 $\mathrm{g}$, which is comparable to the average birth weight of piglets produced by natural breeding (460 g). Furthermore, the growth curve of the live cloned piglets (data not shown) was comparable to that of naturally bred piglets, suggesting that the physical attributes of miniature pigs were maintained even when miniature pig clones were produced using common domestic pig oocytes. Compared with common domestic pigs, miniature pigs produce fewer piglets and the production costs are higher; as a result, establishing a mass production system for cloned miniature pigs by using IVM oocytes derived from abattoir ovaries will further accelerate usage of miniature pigs. However, use of abattoir-derived oocytes as recipient cytoplasts may have hygienic implications. The difference in health status between miniature and common domestic pigs, i.e., parvovirus, porcine reproductive and respiratory syndrome (PRRS) or other diseases widespread in agricultural animal husbandry has to be considered.

Transgenic cloned miniature pigs expressing GFP were also produced using common domestic pig recipients, and piglets were efficiently produced. In particular, five live piglets were obtained from one recipient, and the average birth weight of these piglets was $480 \mathrm{~g}$, which is comparable to that of naturally bred NIBS miniature pigs. In the present study, we did not raise the piglets that were delivered by caesarean section, but we do believe it is feasible to raise these transgenic miniature pigs using foster mothers and artificial milk.

By simultaneously producing miniature pigs expressing a fluorescent marker, such as GFP, and syngeneic non-transgenic cloned pigs, it is possible to prepare highly valuable experimental models. For example, among syngeneic clones, because rejection is not an issue with organ or tissue transplantation $[55,56]$, transplantationrelated experiments can be conducted with a very high level of accuracy and precision. As donors in transplantation experiments, a great many piglets and fetuses may be needed in certain studies. In such cases, clone production using common domestic pig recipients would be highly useful.

Southern analysis of the transgenic miniature pigs was not performed in this investigation, but the fluorescence of all eight organs examined and the primary cultured cells established from these organs, except for the brain, was clear. These findings together with the PCR analysis of the piglets (data not shown) indicated that the transfected gene had integrated into the donor cells used in nuclear transfer. The reason for the very mild fluorescence in the brain tissue was probably certain characteristics of the promoter.

In the present study, the SCNT technique that we had originally 
developed for common domestic pigs was applied to miniature pigs, and we were able to confirm that reconstructed embryos could be efficiently produced. In addition, we demonstrated that both miniature pig and common domestic pig recipients can be used for production of both cloned and transgenic cloned miniature pigs. Hence, a practical system for cloning of miniature pigs has been developed.

\section{Acknowledgements}

The authors would like to acknowledge Dr. A Katsumata and Dr. T Nunoya, Nippon Institute for Biological Science, for their support during this study. This work was supported by Grant for Practical Application of University R\&D Results under the Matching Fund Method from the New Energy and Industrial Technology Development Organization (NEDO), the Program for Promotion of Basic Research Activities for Innovative Biosciences (PROBRAIN) and a "Biotechnology Venture Research and Development Base Maintenance Enterprise” Project for Private Universities subsidy from the Ministry of Education, Culture, Sports, Science and Technology of Japan (2002-2006).

\section{References}

1. Park KW, Cheong HT, Lai L, Im GS, Kuhholzer B, Bonk A, Samuel M, Rieke A, Day BN, Murphy CN, Carter DB, Prather RS. Production of nuclear transfer-derived swine that express the enhanced green fluorescent protein. Anim Biotechnol 2001; 12: 173-181.

2. Lai L, Park KW, Cheong HT, Kuhholzer B, Samuel M, Bonk A, Im GS, Rieke A, Day BN, Murphy CN, Carter DB, Prather RS. Transgenic pig expressing the enhanced green fluorescent protein produced by nuclear transfer using cochicine-treated fibroblasts ad donor cells. Mol Reprod Dev 2002; 62: 300-306.

3. Park KW, Lai L, Cheong HT, Cabot R, Sun QY, Wu G, Rucker EB, Durtschi D, Bonk A, Samuel M, Rieke A, Day BN, Murphy CN, Carter DB, Prather RS. Mosaic gene expression in nuclear transfer-derived embryos and the production of cloned transgenic pigs from ear-derived fibroblasts. Biol Reprod 2002; 66: 1001-1005.

4. Hyun S, Lee G, Kim D, Kim H, Lee S, Nam D, Jeong Y, Kim S, Yeom S, Kang S, Han J, Lee B, Hwang W. Production of nuclear transfer-derived piglets using porcine fetal fibroblasts transfected with the enhanced green fluorescent protein. Biol Reprod 2003; 69: 1060-1068.

5. Lee GS, Kim HS, Hyun SH, Lee SH, Jeon HY, Nam DH, Jeong YW, Kim S, Kim JH, Han JY, Ahn C, Kang SK, Lee BC, Hwang WS. Production of transgenic cloned piglets from genetically transformed fetal fibroblasts selected by green fluorescent protein. Theriogenology 2005; 63: 973-991.

6. Watanabe S, Iwamoto M, Suzuki S, Fuchimoto D, Honma D, Nagai T, Hashimoto M, Yazaki S, Sato M, Onishi A. A novel method for the production of transgenic cloned pigs: electroporation-mediated gene transfer to non-cultured cells and subsequent selection with puromycin. Biol Reprod 2005; 72: 309-315.

7. Kurome M, Ueda H, Tomii R, Naruse K, Nagashima H. Production of transgenicclone pigs by the combination of ICSI-mediated gene transfer with somatic cell nuclear transfer. Transgenic Res 2006; 15: 229-240.

8. Zhang Y, Pan D, Sun X, Sun G, Wang X, Liu X, Li Y, Dai Y, Li N. Production of porcine cloned transgenic embryos expressing green fluorescent protein by somatic cell nuclear transfer. Sci China C Life Sci 2006; 49: 164-171.

9. Dai Y, Vaught TD, Boone J, Chen SH, Phelps CJ, Ball S, Monahan JA, Jobst PM, McCreath KJ, Lamborn AE, Cowell-Lucero JL, Wells KD, Colman A, Polejaeva IA, Ayares DL. Targeted disruption of the alpha1,3-galactosyltransferase gene in cloned pigs. Nat Biotechnol 2002; 20: 251-255.

10. Lai L, Kolber-Simonds D, Park KW, Cheong HT, Greenstein JL, Im GS, Samuel M, Bonk A, Rieke A, Day BN, Murphy CN, Carter DB, Hawley RJ, Prather RS. Production of alpha-1,3-galactosyltransferase knockout pigs by nuclear transfer cloning. Science 2002; 295: 1089-1092.

11. Phelps CJ, Koike C, Vaught TD, Boone J, Wells KD, Chen SH, Ball S, Specht SM, Polejaeva IA, Monahan JA, Jobst PM, Sharma SB, Lamborn AE, Garst AS, Moore M, Demetris AJ, Rudert WA, Bottino R, Bertera S, Trucco M, Starzl TE, Dai Y, Ayares
DL. Production of alpha 1,3-galactosyltransferase-deficient pigs. Science 2003; 299 411-414.

12. Ramsoondar JJ, Machaty Z, Costa C, Williams BL, Fodor WL, Bondioli KR. Production of alpha 1,3-galactosyltransferase-knockout cloned pigs expressing human alpha 1,2-fucosyltransferase. Biol Reprod 2003; 69: 437-445.

13. Dor FJ, Tseng YL, Cheng J, Moran K, Sanderson TM, Lancos CJ, Shimizu A Yamada K, Awwad M, Sachs DH, Hawley RJ, Schuurman HJ, Cooper DK. Alpha1,3galactosyltransferase gene-knockout miniature swine produce natural cytotoxic antiGal antibodies. Transplantation 2004; 78: 15-20.

14. Kolber-Simonds D, Lai L, Watt SR, Denaro M, Arn S, Augenstein ML, Betthauser J, Carter DB, Greenstein JL, Hao Y, Im GS, Liu Z, Mell GD, Murphy CN, Park KW, Rieke A, Ryan DJ, Sachs DH, Forsberg EJ, Prather RS, Hawley RJ. Production of alpha-1,3-galactosyltransferase null pigs by means of nuclear transfer with fibroblasts bearing loss of heterozygosity mutations. Proc Natl Acad Sci USA 2004; 101: 7335-7340.

15. Takahagi $\mathbf{Y}$, Fujimura T, Miyagawa $S$, Nagashima $H$, Shigehisa T, Shirakura $\mathbf{R}$, Murakami H. Production of alpha 1,3-galactosyltransferase gene knockout pigs expressing both human decay-accelerating factor and N-acetylglucosaminyltransferase III. Mol Reprod Dev 2005; 71: 331-338.

16. Fujimura $T$, Murakami $H$, Kurome $M$, Takahagi $Y$, Shigehisa $T$, Nagashima $H$ Effects of recloning on the efficiency of production of alpha 1,3-galactosyltransferaseknockout pigs. J Reprod Dev 2008; 54: 58-62.

17. Bollen PJA, Hansen AK, Rasmussen HJ. The Laboratory Swine. In: Suckow MA (ed.) Boca Raton: CRC Press; 2000

18. Dexter JD, Tumbleson ME, Hutcheson DP, Middleton CC. Sinclair(S-1) miniature swine as a model for the study of human alcoholism. Ann NY Acad Sci 1976; 273: 188193.

19. Phillips RW, Panepinto LM, Spangler R, Westmoreland N. Yucatan miniature swine as a model for the study of human diabetes mellitus. Diabetes 1982; 31: 30-36.

20. Reitman JS, Mahley RW, Fry DL. Yucatan miniature swine as a model for dietinduced atherosclerosis. Atherosclerosis 1982; 43: 119-132.

21. Panepinto LM, Phillips RW. The Yucatan miniature pig: characterization and utilization in biomedical research. Lab Anim Sci 1986; 36: 344-347.

22. Misfeldt ML, Grimm DR. Sinclair miniature swine: an animal model of human melanoma. Vet Immunol Immunopathol 1994; 43: 167-175.

23. Uchida M, Shimatsu Y, Onoe K, Matsuyama N, Niki R, Ikeda JE, Imai H. Production of transgenic miniature pigs by pronuclear microinjection. Transgenic Res 2001; 10 577-582.

24. Vodicka P, Smetana KJ, Dvorankova B, Emerick T, Xu YZ, Ourednik J, Ourednik V, Motlik J. The miniature pig as an animal model in biomedical research. Ann NY Acad Sci 2005; 1049: 161-171.

25. Svendsen $\mathrm{O}$. The minipig in toxicology. Exp Toxicol Pathol 2006; 57: 335-339.

26. Hoshino Y, Uchida M, Shimatsu Y, Miyake M, Nagao Y, Minami N, Yamada M, Imai $\mathbf{H}$. Developmental competence of somatic cell nuclear transfer embryos reconstructed from oocytes matured in vitro with follicle shells in miniature pig. Cloning Stem Cells 2005; 7: 17-26

27. Miyoshi K, Yuki Y, Yoshida M. Optimization of $\mathrm{Ca}^{2+}$ concentrations in fusion and activation media for production of cloned embryos from miniature pig somatic cells. J Reprod Dev 2005; 51: 699-706.

28. Hao YH, Yong HY, Murphy CN, Wax D, Samuel M, Rieke A, Lai L, Liu Z, Durtschi DC, Welbern VR, Price EM, McAllister RM, Turk JR, Laughlin MH, Prather RS Rucker EB. Production of endothelial nitric oxide synthase (eNOS) over-expressing piglets. Transgenic Res 2006; 15: 739-750.

29. Lee E, Lee SH, Kim S, Jeong YW, Kim JH, Koo OJ, Park SM, Hashem MA, Hossein MS, Son HY, Lee CK, Hwang WS, Kang SK, Lee BC. Analysis of nuclear reprogramming in cloned miniature pig embryos by expression of Oct-4 and Oct-4 related genes. Biochem Biophys Res Commun 2006; 348: 1419-1428.

30. Miyoshi K, Sato K, Yoshida M. In vitro development of cloned embryos derived from miniature pig somatic cells after activation by ultrasound stimulation. Cloning Stem Cells 2006; 8: 159-165.

31. Miyoshi K, Inoue S, Himaki T, Mikawa S, Yoshida M. Birth of cloned miniature pigs derived from somatic cell nuclear transferred embryos activated by ultrasound treatment. Mol Reprod Dev 2007; 74: 1568-1574.

32. Petters RM, Wells KD. Culture of pig embryos. J Reprod Fert 1993; 48: 61-73.

33. Kurome M, Fujimura T, Murakami H, Takahagi Y, Wako N, Ochiai T, Miyazaki K Nagashima H. Comparison of electro-fusion and intracytoplasmic nuclear injection methods in pig cloning. Cloning and Stem Cells 2003; 5: 367-378.

34. Yin XJ, Tani T, Yonemura I, Kawakami M, Miyamoto K, Hasegawa R, Kato Y, Tsunoda $\mathrm{Y}$. Production of cloned pigs from adult somatic cells by chemically assisted removal of maternal chromosomes. Biol Reprod 2002; 67: 442-446.

35. Yoshioka K, Suzuki C, Tanaka A, Anas IM, Iwamura S. Birth of piglets derived from porcine zygotes cultured in a chemically defined medium. Biol Reprod 2002; 66: 112 119 
36. Fujimura T, Kurome M, Murakami H, Takahagi Y, Matsunami K, Shimanuki S, Suzuki K, Miyagawa S, Shirakura R, Shigehisa T, Nagashima H. Cloning of the transgenic pigs expressing human decay accelerating factor and $\mathrm{N}$-acetylglucosaminyltransferase III. Cloning Stem Cells 2004; 6: 294-301.

37. Tomii R, Kurome M, Ochiai T, Wako N, Ueda H, Hirakawa K, Kano K, Nagashima H. Production of cloned pigs by nuclear transfer of preadipocytes established from adult mature adipocytes. Cloning Stem Cells 2005; 7: 279-288.

38. Betthauser J, Forsberg E, Augenstein M, Childs L, Eilertsen K, Enos J, Forsythe T, Golueke P, Jurgella G, Koppang R, Lesmeister T, Mallon K, Mell G, Misica P, Pace M, Pfister-Genskow M, Strelchenko N, Voelker G, Watt S, Thompson S, Bishop M. Production of cloned pigs from in vitro systems. Nat Biotechnol 2000; 18: 1055-1059.

39. Onishi A, Iwamoto M, Akira T, Mikawa S, Takeda K, Awata T, Hanada H, Perry ACF. Pig cloning by microinjection of fetal fibroblast nuclei. Science 2000; 289: 11881190.

40. Polejaeva IA, Chen SH, Vaught TD, Page RL, Mullins J, Ball S, Dai Y, Boone J, Walker S, Ayares D, Colman A, Campbell KH. Cloned pigs produced by nuclear transfer from adult somatic cells. Nature 2000; 407: 86-90.

41. Bondioli K, Ramsoondar J, Williams B, Costa C, Fodor W. Cloned pigs generated from cultured skin fibroblasts derived from a $\mathrm{H}$-transferase transgenic boar. $\mathrm{Mol}$ Reprod Dev 2001; 60: 189-195.

42. Lai L, Tao T, Macháty Z, Kühholzer B, Sun QY, Park KW, Day BN, Prather RS. Feasibility of producing porcine nuclear transfer embryos by using G2/M-stage fetal fibroblasts as donors. Biol Reprod 2001; 65: 1558-1564.

43. Boquest AC, Grupen CG, Harrison SJ, McIlfatrick SM, Ashman RJ, d'Apice AJF, Nottle MB. Production of cloned pigs from cultured fetal fibroblast cells. Biol Reprod 2002; 66: 1283-1287.

44. Walker SC, Shin T, Zaunbrecher MZ, Romano JE, Johnson GA, Bazer FW, Piedrahita JA. A highly efficient method for porcine cloning by nuclear transfer using in vitromatured oocytes. Cloning and Stem Cells 2002; 4: 105-112.

45. Lee JW, Wu SC, Tian XC, Barber M, Hoagland T, Riesen J, Lee KH, Tu CF, Cheng WT, Yang X. Production of cloned pigs by whole-cell intracytoplasmic microinjection. Biol Reprod 2003; 69: 995-1001.

46. Lagutina I, Lazzari G, Galli C. Birth of cloned pigs from zona-free nuclear transfer blastocysts developed in vitro before transfer. Cloning Stem Cells 2006; 8: 283-293.

47. Diehl JR, Lipetz KJ, Stuart LD, Wildt DE. Use of exogenous gonadotropin and embryo transfer to study reproductive efficiency in altrenogest synchronized miniature swine. In: Tumbleson ME (ed.), Swine in Biomedical Research. New York: Plenum Press; 1986: 135-142.

48. Diehl JR, Stuart LD, Goodrowe KL, Wildt DE. Effects of altrenogest and exogenous gonadotropins on ovarian function and embryo recovery in swine leukocyte antigen inbred miniature swine as influenced by cystic endometrial hyperplasia. Biol Reprod 1986; 35: 1261-1268.

49. Lipetz KJ, Diehl JR, Stuart LD. Interstrain inseminations and embryo transfers between the SLA miniature pig and standard crossbred pig. Theriogenology 1989; 31 323-329.

50. Pinkert CA, Murray KA. Superovulation and egg transfer in Yucatan miniature swine. Anim Reprod Sci 1993; 31: 155-163.

51. Shimatsu $\mathbf{Y}$, Uchida $\mathbf{M}, \mathbf{N i k i} \mathbf{R}$, Imai $\mathbf{H}$. Induction of superovulation and recovery of fertilized oocytes in prepubertal miniature pigs after treatment with PG600. Theriogenology 2000; 53: 1013-1022.

52. Shimatsu Y, Uchida M, Niki R, Imai H. Effects of a synthetic progestogen altrenogest, on oestrus synchronisation and fertility in miniature pigs. Vet Rec 2004 155: 633-635.

53. Guthrie HD, Polge C. Treatment of pregnant gilts with a prostaglandin analogue Cloprostenol, to control oestrus and fertility. J Reprod Fertil 1978; 52: 271-273.

54. Ueno S, Kurome M, Tomii R, Hiruma K, Saitoh H, Nagashima H. Association between embryonic loss and damage to the zona pellucida by invasive micromanipulation during oviductal transfer of early-stage embryos in pigs. J Reprod Dev 2007; 53 1113-1118.

55. Lanza RP, Chung HY, Yoo JJ, Wettstein PJ, Blackwell C, Borson N, Hofmeister E, Schuch G, Soker S, Moraes CT, West MD, Atala A. Generation of histocompatible tissues using nuclear transplantation. Nat Biotechnol 2002; 20: 689-696.

56. Martin MJ, Yin D, Adams C, Houtz J, Shen J, Chong AS, Sharma A, Byrne GW Wiseman BS, Logan JS. Skin graft survival in genetically identical cloned pigs. Cloning Stem Cells 2003; 5: 117-121. 